\title{
Resilience and Friendship Quality among Late Adolescents from Intact, Divorced, and Remarried Families
}

\author{
Karina Saraswati ${ }^{1 *}$, Julia Suleeman ${ }^{2}$ \\ 1. Dinamika Energi Internasional, Jakarta, Indonesia \\ 2. Faculty of Psychology, Universitas Indonesia, Depok Jawa Barat, Indonesia \\ *E-mail: karinasaras@hotmail.com
}

\begin{abstract}
This research was conducted to find the relationship between resilience and friendship quality among late adolescents. Resilience is the manifestation of individual quality or the ability to cope and survive adversity or change. Friendship quality is an individual judgment of the degree to which a friend fulfills friendship functions. Resilience was measured by Resiliency Attitudes and Skills Profile (RASP) (Hurtes \& Allen, 2001) while friendship quality was measured by McGill Friendship Questionnaire-Friends' Function (MFQFF) from Mandelson and Boud (2012). Participants of this research were 75 late adolescents (males/females, Mage $=\mathrm{X}, \mathrm{SD}=\mathrm{X}$ ) living with biological, divorced, or stepfamily. Results show a positive significant correlation between resiliency and friendship quality among late adolescence from intact, divorced, or remarried families. The implication of this study is the importance of maintaining a good friendship quality for late adolescents who have experienced parental divorce or remarriage in order to develop their resiliency.
\end{abstract}

Keywords: divorced, friendship quality, late adolescence, remarried, resilience

\section{Introduction}

Divorce cases have been increasing throughout the years in Indonesia. In 2009, there were 216.286 cases rising to 324.527 cases in 2013 (www.nasional.republika.co.id). In 2015, there were 347.256 divorce cases reported by the Indonesia Central Bureau of Statistics (https://www.bps.go.id)

Divorce creates impacts to husband, wife, and if they have children, their children, other family members from both husband's and wife's side and their friends. Divorce also creates possibilities to form a new family that constitutes one biological parent, one step-parent, and step sibling(s).

In Indonesia, the majority of studies about divorce are focused on the effects and how adolescents deal with it. No studies about remarried parents were found. Studies have found the description of adolescents' resiliency and coping strategy used but we have not found any study about social agents that can help adolescents in coping with divorce and remarried parents, specifically friends, who cannot be parted from the life of adolescents. This study aims to find the relationship between resiliency and friendship quality among late adolescents from various kind of families; intact, divorced, and remarried.
It will not be easy for a child from divorced families to undergo changes in the family structure. First, the child has to undergo changes from his or her nuclear family to separate families then he or she has to undergo changes again when one parent re-marries. Hetherington (1989) reported that compared to older children in teenage years, younger children appear to be more ready to enter the stage when their parent get married again. In addition, teenagers tend to be more resistant toward the introduction of stepparents compared to younger children or older teenagers. Introducing to new family members might include new family rituals, rules, values that are different from former families and this can make teenagers respond with confusion, interpersonal conflict, and asking the value of him- or herself in the family context (Sweeney \& Bracken, 2000).

When dealing with parental divorce, adolescents are faced with certain challenges that come with the changes in the family structure. According to Wallerstein (1983), there are several developmental tasks for children from divorced families, and they are as the following:

1. Accept that their parents are divorced. This might be the first time that children should distinguish between fantasy and reality about the changes in their family. This might need a year after the divorce takes place. 
2. Do the activities that need to be done. In order to do so, they have to separate themselves from the conflicts that occur between their parents. The divorce that has been the center of the children's attention should be directed to something else.

3. Overcome the feeling of loss of one or more family members and family rituals as the effect of having a parental divorce. In addition to that, there might also be a decrease in income that can cause a decrease in economic status. These are tasks that are so difficult to accomplish. Many children cannot overcome this forever.

4. Overcome the feeling of anger and blaming themselves. In dealing with parental divorce, usually children direct their anger to those they regard as responsible for the divorce. This anger will not decrease until they can forgive and understand their parents' perspective and reason to get divorced. In his study, Wallerstein (1983) found out that some children might take up to 10 years before they can forgive their parents and make peace with them.

5. Accept that parental divorce lasts forever. Children often daydream that their parents can get together again even after each parent remarried with someone else. To get adjusted to parental divorce, children have to overcome their fantasy about their parents being together again.

6. Have a hope for their own romantic relationship for the sake of their own future. Children have to develop realistic opinions about their ability to love and be loved. They have to be brave to take chances in romantic relationships. Many children from divorced families become cynical toward love and think that they will have a similar fate as their parents. They feel that their marriage would also fail as their parents' even though they have tried to find a compatible spouse. Many have low self-esteem and feel pessimistic to have a romantic relationship. If they can see themselves as one who can love and be loved, it means that they have accomplished this important developmental task in handling parental divorce.

Kushner (2009) revealed several longitudinal national studies that demonstrate children's resilience. They found around $20 \%$ to $25 \%$ children from divorced families experience serious psychological, behavioral, and social problems compared to only $10 \%$ from children in intact families. These numbers indicate that $75 \%$ to $80 \%$ adolescents and young adults from divorced families do not have significant problems in adjustment, relation, or social. Kushner also states that the majority of children from divorced families are resilient. Specifically, adolescents became stronger and wiser. In addition to that, children and grandchildren from divorced families understand that divorce can have positive results for themselves and both parents. More than half of his sample agreed that the relationship with their father improved after divorce, and the majority of young adults felt the could connect with the stepfamily members.

The ability of adolescents to successfully handle problems from their parents' marriage might be influenced by risk and protective factors in a different family setting (Kushner, 2009). There are 3 protective factors related with changes in family structure -- positive personality disposition, supportive family environment, and external social agents that function as supporting system to strengthen the child's coping that does not happen automatically, but dependent on the child's willingness and capability to use available sources (Hetherington, 1989). In other words, if there are available sources, but the child does not want to use them, those sources will not give protection. Peer/friendship is one of the protective factors that can act as the supporting system for adolescents.

Adolescents can take advantage of sources outside the family circle like friends because they spend quite a considerable time outside the house. According to Hetherington, Stanley-Hagan, and Anderson (1989) adolescents show their maturity when dealing with parental divorce, and this also leads them to be more independent. But, they can also experience premature detachment from their family. If this detachment directs them to achievement in school and constructive relationship with others outside the family circle, this can be a good coping mechanism that is adaptive and positive. Almost one-third of children become detached from families because of parental divorce and remarriage. These children get more involved in school activities and friends, and they become attached to responsive adults or friend's family (Hetherington, 1989).

Peers are very important for pre-adolescents and adolescents (Rodgers \& Rose, 2002). Birkeland, Breivik, and Wold (2014) state that friendship plays a more important role as adolescents get older and this indicates that being accepted by peers is a protective factor in older adolescents as compared to younger adolescents. Parents are regarded as providing the highest support for early adolescents 
but peers and romantic partners are perceived as more supportive for late adolescents because they can fulfill the similar function as parents. This gives an understanding that peers play a very important role for late adolescents and become a protective factor.

According to Hetherington (1989), adolescents who experience parental divorce, having one supportive friend can mediate the effect of stressful events such as parental divorce or parental remarriage. Having a supportive relationship with one friend can make adolescents resist changes in the family structure including parental divorce and remarriage. Kurdek and Siesky (1980 in Demo \& Acock, 1988) suggest that older children adjust more readily to parents' marriage transitions because they are more Iikely to discuss the situation with friends which may have had similar experiences, to understand that they are not personally responsible, to recognize the finality of the situation, to appreciate both parents for their positive qualities, and to recognize beneficial consequences such as the end of parental fighting and improved relations with parents.

The level of friendship quality and social support from friends are related to positive adjustment and development compared to other aspects of friendship: the presence of friends and the number of friends (Tipton, 2011). Several researchers assume that high friendship quality can have a positive impact on children because it is related to self-esteem, social adjustment, and can increase their ability to handle stressors. Berndt (2002) found that friendships that have more positive features correlated with engagement level in school, perceived social acceptance, and higher general selfesteem.

Inkrott (1988) concluded that adolescence is the most difficult period for children to adjust into a stepfamily and the older the child is, the more difficult it is to build a relationship with a step parent. Adolescents who have parental divorce will undergo a series of changes and disturbances in terms of familial relationship including having a change in the emotional relationship when one or both parents start developing a relationship with another spouse (Kelly \& Emery, 2003). Girls from divorced or remarried families tend to share and use peers as social support while boys tend to spend time with themselves or with their peers compared with their families (Rodgers \& Rose, 2002).

Richardson (2002) defines resilience as "the process of coping with adversity, change, or opportunity in a manner that results in the identification, fortification, and enrichment of resilient qualities or protective factors (p.214)". The basic assumption of resilience is that individuals have their own strengths as the protective factor that can help them to be resilient in difficult situations. According to Connor dan Davidson (2003), resilience can be perceived as a successful measure of coping and stress. It can be concluded that resilience is the expression of the personal quality or individual capability in coping with difficulties and changes.

Children who experience parental divorce can grow into competent individuals who able to handle stress and difficulties so they can be called resilient children. According to Rodgers and Rose (2002), resilient children and adolescents have the protective factor as part of the character that helps them from negative events or stress they faced -such as having a close relationship with adults or supportive friends that can help balance negative impact from the stressful environment. The resilient model states that the presence of friends help them share. Attachment to school or close relationship with caring adults besides their own parents might provide a protective function for adolescents who experience changes in family structure because of parental divorce.

Short and Russell-Mayhew (2009) described resilient adolescents as emotionally healthy individuals who are able to successfully confront and negotiate a multitude of challenges, and effectively cope with obstacles, barriers, or setbacks. They appear to possess certain qualities or characteristics that differentiate them from those who are not able to successfully meet challenges or effectively deal with personal setbacks.

Rabaglietti and Ciairano (2008) also explained that peers represent a normative and comparative reference for adolescents and are a source for selfreorganization and identity construction. Support from friends has a positive impact on success in school, the value of autonomy, and dating. Friendship is a fundamental source for adolescents because it provides various instrumental, cognitive, and emotional help. Talking and brainstorming with peers helps adolescents to gain a deeper understanding of problems they have to solve. Peers could be a crucial source of adolescent's adjustment in general.

Friendship quality was assumed by Mandelson and Aboud (2012) as an individual's assessment of the degree to which friends fulfill friendship functions. Tipton (2011) identified 6 relevant friendship 
functions -- stimulating companionship, help, intimacy, reliable alliance, self-validation, and emotional security. It is assumed that friends fulfill some, if not all, of these functions. Stimulating Companionship refers to doing things together that arouse enjoyment, amusement, and excitement. This quality seems to be an important expectation of friends of all ages. Help refers to providing guidance, assistance, information, advice, and other forms of tangible aid necessary to meet needs or goals. Intimacy refers to sensitivity to the other's needs and states, providing an accepting context in which personal thoughts and feelings can be openly and honestly expressed, and openly and honestly disclosing personal information about oneself. Reliable Alliance refers to being able to count on the continuing availability and loyalty of the friend. Self-Validation refers to perceiving the other as reassuring, agreeing, encouraging, listening, and otherwise helping to maintain one's self-image as a competent and worthwhile person. This is often achieved through social comparison and consensual validation of one's attributes and beliefs. Emotional Security refers to the comfort and confidence provided by the friend in novel or threatening situations. Our hypothesis is that there will be a positive correlation between resilience and friendship quality among late adolescents.

\section{Methods}

Sample. The participants were late adolescents who lived with intact (biological related), divorced (divorce happened when both parents are alive, not because one of them pass away), or remarried (stepfamily). All participants in this study were undergraduate students at Jakarta and Bandung area, some of them lived in a boarding house outside the city during school period and go home on holidays or weekends. The sample included 75 late adolescents (36 males and 39 females) with age ranging from 20-24 years from intact, divorced, and remarried families (25 participants each). Sampling technique used was accidental and snowball sampling.

Instruments. In this study, the instruments used were the measurement of resiliency and friendship quality. Resiliency was measured by Resiliency Attitudes and Skills Profile (RASP) developed by Hurtes and Allen (2001) and McGill Friendship Questionnaire-Friend's Functions (MFQ-FF) developed by Mandelson and Aboud (2012). All items in RASP were measured on a 6-point scale from $1=$ strongly disagree to $6=$ strongly agree. MFQ-FF used 5-point response scale from $1=$ never to $5=$ always. Both measurements were translated and back-translated to and from Indonesian language and tested through expert judgment by two lecturers from the Faculty of Psychology, Universitas Indonesia.

The reliability and validity check was also carried on. For RASP that has 34 items, the Cronbach coefficient-alpha was 0.863 , and the correlation with other resiliency measurement (ConnorDavidson Resilience Scale or CD-RISC) indicated that RASP was valid $(r=.487, p=<.01)$. The MFQ-FF measurement has 30 items with a Cronbach coefficient-alpha of .927 and all corrected item-total correlations were above .2 except for item number 9 and 13 which were still used in this study because their respective item validity values of .191 and .194 were considered not too low from the minimum validity value. The reliability and validity check for RASP and MFQ-FF were completed with 61 late adolescents regardless of their family background.

Personal interviews were conducted with four participants who were late adolescents with one male and one female participant from each of divorced and remarried family, respectively. The interviews conducted using a semi-structured interview and were aimed to understand the struggles and tension the participants went through when their parents got divorced or remarried, how they handled the stress arouse during that difficult times, and how their friends had helped them. The interviews took place in coffee shops and participants' houses for 1-1,5 hours.

\section{Results}

From both measurements used; Resiliency Attitudes and Skills Profile (RASP) and McGill's Friendship Questionnaire-Friends' Function (MFQ-FF), below is descriptive data:

Table 1.

Scores of RASP and MFQ-FF

\begin{tabular}{lcccc}
\hline & \multicolumn{2}{c}{ RASP } & \multicolumn{2}{c}{ MFQ-FF } \\
\hline & Range & $\begin{array}{c}\text { Mean } \\
(\mathrm{SD})\end{array}$ & Range & $\begin{array}{c}\text { Mean } \\
(\mathrm{SD})\end{array}$ \\
\hline Intact & $133-174$ & $\begin{array}{l}156.24 \\
(11.85)\end{array}$ & $99-148$ & $\begin{array}{l}127.24 \\
(14.11)\end{array}$ \\
Divorced & $126-197$ & $\begin{array}{l}158.16 \\
(17.71)\end{array}$ & $105-150$ & $\begin{array}{l}130.96 \\
(13.16)\end{array}$ \\
Step & $115-200$ & $\begin{array}{l}163.6 \\
(21.42)\end{array}$ & $96-150$ & $\begin{array}{l}127 \\
(14.75)\end{array}$ \\
\hline Total & $115-200$ & $\begin{array}{l}159.33 \\
(17.17)\end{array}$ & $96-150$ & $\begin{array}{l}128.4 \\
(13.95)\end{array}$ \\
\hline
\end{tabular}

According to Table 1, Compared to adolescents from intact and divorced families, those from 
stepfamilies have a wider range including higher mean on RASP. But those from divorced families have a wider range and higher mean of MFQ-FF.

\section{b. ANOVA on resilience and friendship quality}

ANOVA was carried to find whether there were significant differences between gender and among those from three different familial backgrounds. For resilience, there were no differences between gender, and among intact, divorced and remarried families $\left(F\right.$ gender $(1,73)=1.73, p=.343 ; F_{\text {families }}(2$, $72)=1.101, p=.338)$. These results indicate that all participants have comparable resilience, regardless of gender and familial background.

ANOVA on friendship quality also revealed no sigificant differences between gender and among the three different familial background $(F$ gender $(1,73)=1.73, p=.343 ; F$ families $(2,72)=1.101, p=$ $.338)$.

\section{c. Relationship between resilience and friendship quality}

Results of the Pearson correlation indicated that there was a significant positive correlation between resilience and friendship quality among late adolescents from intact, divorced, and remarried families, $(r(74)=.309, p<001)$.

\section{d. Results from personal interviews}

From the interviews, we gained an understanding that both participants who lived with their single parents experience stress because parents' divorce is commonly a result from parents' fights. Meanwhile participants who live with remarried families felt that divorce was the best way to resolve conflict in the family and the heaviest stress arose from the divorce, not the remarried event. The biggest pressure in facing a parents' divorce according to the participants was accepting the divorced reality and parting with biological family. Participants who have stepfamilies admitted that the remarried event did not contribute much to the pressure taken by themselves because they felt more pressured by their parents' divorce. They said that accepting the remarried event was something that they did not need to think of much and did not give pressure as big as when they faced parents' divorce. Adjustments made by adolescents with the remarried family model was also not perceived as something that was pressuring. Aside from adjusting with the new family model, adolescents who faced parents' divorce and remarried also had to adjust to the new family economy condition -- one of the participants had to change her daily activities and it gave another pressure though not as heavy as losing one of the biological parents.

In handling the stress arose because of divorce, male participants tended not to talk about it to their friends and search for distractions, meanwhile female participants engaged with their friends more to pour out their heart. In general, participants' friends were described as giving supports in various ways, some with being a place to talk to and other with providing time to do activities together.

\section{Discussion \& Conclusion}

Discussion. The finding that there was a significant correlation between resiliency and friendship quality among late adolescents indicates the role of positive friendship quality to adolescents' resiliency. This result aligns with Rodgers and Rose (2002) who noted that the presence of friends to confide in may serve as a protective function to adolescents who have experienced marital transition because of parents' divorce allowing adolescents to buffer the effects that arise and increase their resiliency.

ANOVAs found that there was no difference among adolescents from intact, divorced, and remarried families. This might be because every family structure has its own challenges; divorce usually includes high family conflict level and the decrease or loss contact with one of the biological parent, meanwhile remarried event includes an addition of new family members. Children from remarried parents have gone through periods of living with their biological parents, divorce, and single parent before entering the remarried event. In the previous study, the behavior of children in stepfamilies was attributed not to the difficulty in adapting to remarried parents, but with the stress associated with divorce and their life with the single parent (Furstenberg, 1988; Zill, 1988). It is supported by the interview result with this study as participants said that the heaviest thing is facing their parents' divorce and not the forming of a stepfamily. Accepting remarried event of their parents is perceived as easier to face than the divorce of their parents because the "hardest part" of the condition is passed, which is losing a biological parent. Therefore, there was no significant difference between adolescents from divorced and remarried family.

Furthermore, the long-term effect of marital transition is more correlated with new stress face by 
the child, child's individual attributes, home environment within the family with single parent and stepfamily, and supporting system resources available for the child compare to the remarried event itself (Forgatch, Patterson, \& Skinner, 1988; Zill, 1988). One of the participants also said that she still had a chance to meet her biological parent so she did not feel losing one of her parent figures.

Hetherington (1989) found one of the difficulties faced in her attempts to assess the long-term effect of divorce on parents and children and the factors that may mediate these outcomes was that sequences of family reorganizations and family experiences following divorce vary widely. She also said that most family members undergo an initial period of emotional distress and disrupted functioning following divorce but recover within a 2 to the 3-year period if the divorce is not compounded by continued stress and adversity. Also, the timing of these events may be critical in predicting the long-term adjustment of family members. During the first 2 years following the divorce, most children and many parents experienced emotional distress; psychological, health, and behavior problems; disruptions in family functioning; and problems in adjusting to new roles, relationships, and other life changes associated with the altered family situation. However, as is reported in other studies (Hetherington, Cox, \& Cox, 1982), by 2 years following the divorce, the majority of parents and children were adapting reasonably well and certainly were showing great improvement since the time of the divorce. It means that there are many other factors that can influence the coping process of adolescents in facing divorce or remarried event. Therefore, further study is needed to provide effect sizes for each familial background.

This study also did not find any differences in adolescents' resiliency between genders. It is supported by Hussong (1996) who said that studies about gender differences in friendship quality have conflicting results. Hussong (1996) gathered data from various studies which found that female friendships were more intimate compared to male but this other study (Berndt \& Perry, 1986; ClarkLempers et al., 1991; Furman \& Buhrmester, 1985, 1992; Sharabany et al., 1981) reported that males and females were not different in friendship intimacy and conflict. It is also supported by the interview result that brings us an understanding that both male and female participants have supportive friends despite the difference in the way of support given.
In this study, there is a limitation in the age range that is too narrow, as the data gathered is only from adolescents aged 20-24 years with high level of education. At the age of 20-24 years, most of adolescents have started to build romantic or dating relationship so they can feel the dynamics in building romantic relationship themselves that is might not be as easy as imagined, with many of tolerances have to be given to their partner and conflicts that may result in fights or even breaking up. It may allow them to understand more than romantic relationships are not always about fun but also need hard work in maintaining the relationship.

The findings from this study can be used by parents, teachers, and adolescents' peers who face parents divorce or remarried event to understand deeper of what adolescents are facing and to help them face the challenges and stress to increase their resilience. Most of the time, parents perceived the children's behavior of spending too much time outside the house with their friends as a behavior that can be negative. With this study result, we hope that there will be an understanding of a good quality friendship can also cause positive things for adolescents. The presence of supportive friends has been shown to have a positive correlation with adolescents' resiliency. That being said, adolescents can be helped to gain resiliency, for instance by providing time, facility, and the right stimulus so adolescents can build a good friendship quality in order to help themselves. Other social agents can also give supports by providing good relationships with adolescents.

Conclusions. Resilience was found related to friendship quality among late adolescents, and this was evidenced regardless of the familial background they came from, and whether their parents were married, divorced, or remarried.

\section{References}

Berndt, T. J. (2002). Friendship quality and social development. Current directions in psychological science, 11(1), 7-10.

Benard, B. (2004). Resiliency: What We Have Learned. San Francisco: WestEd.

Birkeland, M. S., Breivik, K., \& Wold, B. (2014). Peer acceptance protects global self-esteem from negative effects of low closeness to parents during adolescence and early adulthood, Journal of Youth Adolescence, 43, 7080.

Connor, K. M. \& Davidson, J. R. T. (2003). Development of a new resilience scale: The Connor-Davidson Resilience Scale (CD-RISC). Depression and Anxiety, 18, 76-82.

Demo, D. H. \& Acock, A. C. (1988). The impact of divorce on children, Journal of Marriage and the Family, 50, 619648. 
Furstenberg Jr, F. F. (1988). Child care after divorce and remarriage. In E. M. Hetherington \& J. D. Arasteh (Eds.). Impact of divorce, single parenting and step parenting on children (pp. 245-261). Hillsdale, NJ: Erlbaum.

Forgatch, M. S., Patterson, G. R., \& Skinner, M. L. (1988). A mediational model for the effect of divorce on antisocial behavior in boys.

Hetherington, E. M., Stanley-Hagan, M. \& Anderson, E. R. (1989). A marital transition: child's perspectives, American Psychologist, 44(2), 303-312.

Hetherington, E. M (1989). Coping with family transitions: winners. losers, and survivors, Child Development, 60(1), $1-14$.

Hurtes, K. P. \& Allen, L. R. (2001). Measuring resiliency in youth: the resiliency attitudes and skills profile, Therapeutic Recreation Journal, 35(4), 333-347.

Hussong, A. M. (1996). Gender Differences in Adolescent Friendships and Adjustments. Disertasi: Arizona State University.

Inkrott, R. H. (1988). The effects of divorce and remarriage on adolescents: a path analysis (Doctoral dissertation, The Ohio State University).

Kelly, J. B. \& Emery, R. E. (2003). Children's adjustment following divorce: Risk and resilience perspectives, Family Relations, 52(4), 352-362.

Kushner, M. A. (2009). A review of the empirical literature about child development and adjustment post-separation, Journal of Divorce \& Remarriage, 50, 496-516.

Mandelson, M. J. \& Aboud, F. (2012). McGill Friendship Questionnaire Respondent's affection (MFQ-RA). Measurement Instrument Database for the Social Science. Retrieved from www.midss.ie

Papalia, D. E., Olds, S. W., \& Feldman, R. D. (2001). Human Development (8th ed.). New York: McGraw-Hill.
Richardson, G. E. (2002). The metatheory of resilience and resiliency. Journal of clinical psychology, 58(3), 307-321.

Rodgers, K. B. \& Rose, H. A. (2002). Risk and resiliency factors among adolescents who experience marital transition, Journal of Marriage and Family, 64(4), 10241037.

Santrock, J. W. (2011). Adolescence (14th ed.). New York: McGraw-Hill.

Sarwono, S. W. (2010). Psikologi Remaja. Jakarta: Rajawali Pers.

Short, J. L. \& Russell-Mayhew, S. (2009). What counsellors need to know about resiliency in adolescents, International Journal of Advanced Counselling, 31, 213227.

Sweeney, R., \& Bracken, B. A. (2000). Influence of family structure on children's self-concept development, Canadian Journal of School Psychology, 16(1), 39.

Tipton, L. A. (2011). A Study of the Friendship Quality in Adolescents With and Without an Intellectual Disability. Thesis University of California Riverside: eScholarship.

Wallerstein, J. S. (1983). Children of Divorce: Stress and Developmental Tasks. In Garmezy, N. \& Rutter M. (Ed). Stress, coping, and development in children. New York: McGraw-Hill.

http://nasional.republika.co.id/berita/nasional/umum/14/11/14/n f0ij7-tingkat-perceraian-indonesia-meningkat-setiaptahun-ini-datanya

https://www.bps.go.id/linkTableDinamis/view/id/893

Zill, N. (1988). Behavior, achievement, and health problems among children in stepfamilies: Findings from a national survey of child health. In E. M. Hetherington \& J. D. Arasteh (Eds.). Impact of divorce, single parenting and step parenting on children (pp. 245-261). Hillsdale, NJ: Erlbaum. 